\title{
Prescribed Fire Effects on Deciduous Oak Woodland Stand Structure, Northern Diablo Range, California
}

\author{
Danny L. Fry \\ Author is Staff Research Associate, Dept of Environmental Science, Policy, and Management, 137 Mulford Hall, University of California, Berkeley, \\ CA 94720-3114, USA.
}

\begin{abstract}
Despite the increasing use of fire in managing oak woodlands, little information exists on quantitative changes to stand structure from prescribed burning. Fire damage and recovery in a mixed deciduous oak woodland were recorded after a prescribed fire on the northern Diablo Range, Santa Clara County, California. Blue oak (Quercus douglasii Hook. \& Arn.), valley oak (Q. lobata Nee), and black oak (Q. kelloggii Newb.) trees were monitored for $4 \mathrm{yr}$ to determine the effects of a late spring burn on stand structural characteristics. Fire-caused mortality was low; 4 yr after the low intensity ground fire only four oaks died $(1.9 \%)$. There were significant differences in mean percent tree crown scorch and mean trunk char height between plots that burned under different fire intensities, but not between tree size classes. Although overall tree damage was low, crown resprouts developed on $80 \%$ of the trees and were found as shortly as $2 \mathrm{wk}$ after the fire. Recovery was vigorous; both valley oaks and blue oaks produced crown resprouts on trees with $100 \%$ crown scorch. Classification tree analysis identified aspect (mostly southern exposures) and tree size related to the presence of crown resprouting. Crown damage was also an important factor; trees with greater than $40 \%$ of their crown scorched resprouted. Fire-induced trunk scars occurred on a small number of trees $(9.1 \%)$ but was disproportionately higher for black oak compared to blue and valley oak. Stand structural characteristics (species composition, tree density, basal area, and crown closure) were not substantially altered by the event but rather maintained. Prescribed fire might be a viable tool in reducing fuels and maintaining oak woodlands; however, further investigations that include relationships of regeneration with repeated fire are needed.
\end{abstract}

\section{Resumen}

A pesar del incremento en el uso del fuego para el manejo de áreas arboladas de encino, existe poca información sobre los cambios cuantitativos en la estructura de población debido a la quema prescrita. Los daños y recuperación de un bosque mixto de encino fueron evaluados después de una quema prescrita en un pastizal norteño de Diablo, en el condado de Santa Clara, California. Encino azul (Quercus douglasii Hook \& Arn.), encino del valle (Q. lobata Nee), y encino negro (Q. kelloggii Newb.) fueron monitoreados por cuatro años para determinar el efecto de quemas al finalizar la primavera sobre las características estructurales de la población. La mortalidad debido al fuego fue baja; cuatro años después de un fuego de baja intensidad se observó una reducida mortandad $(1.9 \%)$ de encinos. Se encontraron diferencias significativas en daños a la corona y altura media de la corteza entre parcelas que se quemaron bajo diversas intensidades, pero no así entre los diferentes tamaños de árbol. Aunque, el daño hacia los árboles fue poco, dos semanas después del fuego se observaron rebrotes de la corona en un $80 \%$ de los árboles. La recuperación fue vigorosa; los encinos del valle y los encinos azules produjeron brotes basales en árboles con quemaduras en $100 \%$ de la corona. El análisis de la clasificación del árbol identificó el aspecto (especialmente exposiciones del lado sur) y el tamaño del árbol como factores relacionados con la presencia de brotes basales. El daño causado a la corona fue también un factor importante; los árboles con más del $40 \%$ de su corona chamuscada rebrotaron. El fuego causo algunas cicatrices en el tronco en un número pequeño de árboles $(9.1 \%)$ pero fue desproporcionadamente más alto en encino negro comparado con los encino azul y del valle. Las características estructurales de la población (composición de especies, densidad del árbol, área basal, y características de la corona) no se alteraron substancialmente por el fuego sino que se mantuvieron. El uso del fuego prescrito puede ser una herramienta viable para la reducción de combustibles y mantenimiento de áreas arboladas de encino; sin embargo, se requieren otras investigaciones que incluyan el estudio de la relación de características inherentes a la regeneración con el uso repetido del fuego.

Key Words: Blue Oak Ranch Reserve, classification tree, crown closure, fire scar, Quercus, resprout, tree mortality

\section{INTRODUCTION}

Oak-dominated woodlands are one of the most expansive vegetation types in California, covering several million hectares (Griffin 1977; Bolsinger 1988). Oaks have evolved with fire for

Correspondence: Danny L. Fry, Dept of Environmental Science, Policy, and Management, 137 Mulford Hall, University of California, Berkeley, CA 94720-3114, USA. Email: dfry@nature. berkeley.edu

Manuscript received 10 October 2007; manuscript accepted 20 February 2008. millennia and many species possess the ability to survive periodic burning (Pavlik et al. 1991). Although response to fire varies among species, characteristics such as thick bark and epicormic sprouting allow oaks to withstand low- to moderateintensity fires. Conversely, increased fire intensities can cause high levels of mortality (Plumb 1979; Plumb and Gomez 1983).

Fire is an important ecological process responsible for modifying fuel abundance and arrangement (Newell 1983; Tietje et al. 2002; Vreeland and Tietje 2002), influencing nutrient cycling and altering stand structure and successional 
patterns (Allen-Diaz and Bartolome 1992; Swiecki et al. 1997; Lee and Tietje 2005; Wills 2006). Due to the lengthening of fire return intervals from fire suppression, accumulated fuels and ingrowths of shrubs and pines in oak woodlands have created conditions for possible increases in fire hazard (Griffin 1977; Parsons 1981; Reid and Sugihara 1987; Barnhart et al. 1996). Increasing densities of herbaceous and woody fuels and understory vegetation create conditions in which "ladder" fuels allow fires to more easily reach the canopy, making trees more susceptible to death (Mensing 1992; Horney et al. 2002).

Even as the policy of fire suppression continues to be enforced, prescribed burning has been used in some areas to manage oak woodlands for forage production and limit fuel buildup (Griffin and Muick 1984; California Department of Forestry and Fire Protection [CDF] 1996; Swiecki et al. 1997; Tietje et al. 2001). However, the limited use of fire in this vegetation type has provided little fire effects information on oaks (Barbour 1988), especially using prescribed fire. Numerous studies have documented fire effects on deciduous oak seedlings and saplings (Allen-Diaz and Bartolome 1992; Mensing 1992; Swiecki et al. 1997; Tietje et al. 2001; Bartolome et al. 2002; Swiecki and Bernhardt 2002) and adult trees (Plumb 1979; Griffin 1980; Plumb and Gomez 1983; McClaran and Bartolome 1989; Haggerty 1994; Horney et al. 2002; Franklin et al. 2006). Most of these studies have taken advantage of the opportunity to examine fire effects from wildfires that have burned through oak woodlands. Managers might benefit from information on relationships between prescribed fire damage, post-fire recovery and survival, and how prescribed fire can alter oak woodland stand structure (Griffin 1977; Haggerty 1994).

The purpose of this study was to assess the immediate damage and subsequent recovery of blue oak (Quercus douglasii Hook. \& Arn.), valley oak (Q. lobata Nee), and black oak (Q. kelloggii Newb.) trees over a period of $4 \mathrm{yr}$ after a late spring prescribed fire and describe any resulting changes to stand structure. Specifically, the objectives were as follows: 1) to record weather conditions and fire behavior during the fire to identify areas of the unit differing in fire intensity; 2) to determine the extent of fire damage to trees in plots with different fire intensities; 3 ) to determine the degree of recovery and survivorship and changes to stand structure; and 4) to assess what tree, damage, and site characteristics might be good predictors of recovery and mortality.

\section{METHODS}

\section{Study Site}

This research was conducted within the newly acquired Blue Oak Ranch Reserve, a 1320-ha research site under the University of California Reserve System, in the northern Diablo Range, Santa Clara County, California. Mean annual precipitation is $59 \mathrm{~cm}$ and mean seasonal temperatures for winter and summer are $8^{\circ} \mathrm{C}$ and $17^{\circ} \mathrm{C}$, respectively. Although the burn site is predominantly west-facing, narrow, deeply cut drainages create a rolling terrain with steep slopes. Concomitantly, the oak woodlands vary in cover and species assemblage ranging from single black, blue, and valley oak stands to mixed codominance. Associated overstory species, coast live oak (Quercus agrifolia Nee), California buckeye (Aesculus californica [Spach] Nutt.), California bay
(Umbellularia californica [Hook. \& Arn.] Nutt.), and western sycamore (Platanus racemosa Nutt.) are relatively rare and found exclusively in drainages and on mesic slopes.

The understory vegetation is grassland consisting primarily of introduced annual grasses and forbs dominated by brome (Bromus spp.), wild oats (Avena spp.), hedgehog dogtail grass (Cynosurus echinatus L.), geranium (Geranium dissectum L.), clover (Trifolium spp.), and filaree (Erodium spp.). Populations of native grasses found on the site are dominated by purple needlegrass (Nassella pulchra [A. Hitchc.] Barkworth), blue wildrye (Elymus glaucus Buckley), and California melic (Melica californica Scribner).

\section{Burn Day Conditions}

The 124-ha burn was conducted on the west-facing slopes of Poverty Ridge (lat $37^{\circ} 25^{\prime} \mathrm{N}$, long $121^{\circ} 45^{\prime} \mathrm{W}$, elevation $800 \mathrm{~m}$ ) on 24 June 1999. Overall fire intensity was low and consequently limited damage to trees. This burn can be classified as a low to moderate surface fire where most of the understory vegetation, typical of a fuel model 1 as described by Anderson (1982), was consumed except for patches in drainages and on mesic slopes under denser canopies. Estimates of fireline intensity ranged from 15 to $750 \mathrm{~kW} \cdot \mathrm{m}^{-1}$ using observations of flame length, fuel, and weather conditions at the time of the fire (Rothermel 1983). Dead herbaceous fine fuel moisture estimated from weather conditions ranged from $6 \%$ to $8 \%$ (Rothermel 1983).

Weather conditions at time of ignition (1030 hours) were $20^{\circ} \mathrm{C}, 55 \%$ relative humidity $(\mathrm{RH})$, and a southwest wind at $3-$ $7 \mathrm{~km} \cdot \mathrm{h}^{-1}$. During this time the unit burned under backing and flanking conditions; fire intensity was relatively low with flame lengths ranging from several centimeters to $0.5 \mathrm{~m}$. The bottom of the unit was ignited in the early afternoon where it burned under head fire conditions towards the burned areas upslope. Weather conditions during this time (1400 hours) were $22^{\circ} \mathrm{C}$, RH at $42 \%$, and a northwest wind at $3-7 \mathrm{k} \cdot \mathrm{h}^{-1}$. The drier conditions strongly influenced fireline intensity and produced brief periods of flame lengths up to $2.5 \mathrm{~m}$. Trees in this area were exposed to higher heat intensities and many had completely scorched crowns. There were a few incidences of lower canopy leaves catching fire.

The burn area was stratified by aspect into four plots with an effort to capture the variation in fire intensity: northeast (NEAST), northwest (NWEST), southeast (SEAST), and southwest (SWEST). The NEAST plot, located on the east side of the ridge near the ignition point was the first area to burn under low intensities. The NWEST and SEAST plots burned under variable fire intensities through the midday. Lastly, the SWEST plot was the last to burn under primarily head fire conditions.

Two parallel line transects were randomly placed along a baseline transect located on the edge of each of the four plots (in August 1999). At randomly selected points along each parallel transect, the point-centered quarter sampling method (Cottam and Curtis 1956) was used to select trees for surveying damage and monitoring recovery. Slope, aspect, and crown closure using a concave spherical densitometer were recorded at each point. The area around each point was divided into four quarter sections where the closest tree in each section was measured for point-tree-distance, species, diameter at breast 
height (DBH; $1.37 \mathrm{~m}$ height above ground level), and fire damage.

Given that blue and valley oak are in the same oak subgroup, Lepidobalanus, there is potential for hybridization (Pavlik et al. 1991). Indeed, trees with an apparent mixture of morphological characteristics were observed in the field. However, only four apparent hybrids were identified in the survey and considering them a separate species would be impractical for analytic purposes due to the small sample size. Therefore, species assignment for these trees was based on observations of most obvious morphological traits.

Measurements of fire damage and recovery included maximum trunk char height $(\mathrm{m})$, presence of new and old trunk scars, a visual estimation of percent of the crown scorched $(10 \%$ size classes; Haggerty 1994; Horney et al. 2002), and resprouting responses. Trees did not abscise scorched leaves following the fire, allowing for an estimate of crown damage and a preburn estimate of crown closure. Postburn surveys of points on line transects were conducted within 1 mo after the fire and during the summer of 2001 and 2003.

Attributes of stand structure were obtained from information collected using the point-centered quarter technique. Trees that died after the fire were replaced by the next closest tree in the section quarter to determine changes to stand structure. Tree density was calculated using point-tree-distances in the equation from Pollard (1971). Basal area per hectare was computed by multiplying the mean basal area per tree by the density per species.

\section{Analysis}

Variables of fire damage (percent crown scorch and trunk char height) were tested for significant differences between plots varying in fire intensity and tree sizes using nonparametric analysis of variance (Kruskal Wallis test) with Nemenyi pairwise multiple comparisons (Zar 1999). Chi-square tests were used to determine if there were differences in the presence of new fire scars on tree trunks and postburn resprouting between plots varying in fire intensity. Classification trees (CT; Breiman et al. 1984) identified those characteristics related to the binary response variables: tree resprouting and trunk scarring. A CT is constructed by repeatedly splitting the data into two mutually exclusive groups by maximizing the homogeneity of each group according to an explanatory variable. The number of terminal nodes, or leaves, was controlled by choosing the best trade-off between explained deviance and tree size (Breiman et al. 1984; De'ath and Fabricius 2000). Independent variables used in the models include fire damage, tree species and size, and site characteristics such as slope, aspect, and crown closure. Repeated measures analysis of variance (rmANOVA) was used to test for significant differences in mean crown closure between measurements taken immediately after the fire (1999) and two postburn measurements (2001 and 2003).

\section{RESULTS}

\section{Stand Structure}

The study area is moderately steep with an average slope of $38.1 \%$ (range, 6\%-66\%). Average crown closure was $46.1 \%$,
Table 1. Oak woodland stand structure characteristics in the northern Diablo Range, California. Measurements were collected on line transects after a late-spring prescribed burn in 1999 (Preburn) and 4 yr later (Postburn). Density is in number of stems per hectare. BA, basal area $\left(\mathrm{m}^{2} \cdot \mathrm{ha}^{-1}\right)$.

\begin{tabular}{lrrrrrrrr}
\hline & \multicolumn{3}{c}{ Preburn } & & \multicolumn{3}{c}{ Postburn } \\
\cline { 2 - 4 } \cline { 7 - 9 } \multicolumn{1}{c}{ Species } & $n$ & Density & BA & & $n$ & Density & BA \\
\hline Black oak & 19 & 6.2 & 4.2 & & 19 & 5.9 & 4.1 \\
Blue 0ak & 63 & 20.5 & 4.5 & & 63 & 19.6 & 4.3 \\
Valley oak & 116 & 37.7 & 15.1 & & 115 & 35.8 & 14 \\
Bay & 3 & 1 & 0.7 & & 3 & 0.9 & 0.7 \\
Buckeye & 7 & 2.3 & 1 & & 7 & 2.2 & 0.9 \\
Coast live oak & 3 & 1 & 0.2 & & 4 & 1.3 & 0.3 \\
\hline
\end{tabular}

although there was large variation (range, 0\%-97\%). The dominant tree was valley oak, which accounted for $55 \%$ of the total live tree density (68.6 stems $\cdot \mathrm{ha}^{-1}$ ) and $58.9 \%$ of the total live basal area $\left(25.6 \mathrm{~m}^{2} \cdot \mathrm{ha}^{-1}\right)$. Valley oaks were two and six times more frequent than blue oaks and black oaks, respectively. Although black oaks were encountered one third as often as blue oaks, their basal areas were similar. The three deciduous oak species together comprised $93.8 \%$ of total tree density and $92.7 \%$ of the total basal area. Associated hardwood species were a minimal component in the study area (Table 1).

\section{Fire Damage}

Overall, trees received minimal crown scorch from the fire (Table 2; Fig. 1). Most of the trees (78.2\%) had less than 50\% crown scorch. Of the 21 black oak trees sampled, only one had greater than $50 \%$ crown scorch. There was no significant difference in fire damage characteristics for tree size (KruskalWallis test statistic [KW] for scorch $=8.022, \mathrm{df}=9, P=0.532$; for trunk char height, $\mathrm{KW}=8.369$, $\mathrm{df}=9, \quad P=0.497)$.

Table 2. Site and tree damage characteristics by plot in deciduous oak woodlands $4 \mathrm{yr}$ after a late-spring prescribed fire on the northern Diablo Range, California. Values in parentheses represent one standard error of the mean. In rows, means with different letters indicate significant differences $(P<0.05)$. Sites are northeast (NEAST), northwest (NWEST), southeast (SEAST), and southwest (SWEST).

\begin{tabular}{|c|c|c|c|c|}
\hline & \multicolumn{4}{|c|}{ Low $\leftarrow$ Fire Intensity $\rightarrow$ High } \\
\hline & NEAST & NWEST & SEAST & SWEST \\
\hline \multicolumn{5}{|l|}{ Site characteristics } \\
\hline No. oak trees & 52 & 64 & 48 & 44 \\
\hline General aspect $\left({ }^{\circ}\right)$ & 50 & 305 & 180 & 238 \\
\hline Mean slope (\%) & $34.8(1.6)$ & $41.3(1.1)$ & $32.2(2.1)$ & $43.8(1.8)$ \\
\hline \multicolumn{5}{|l|}{ Fire damage } \\
\hline Mean crown scorch (\%) & $9.0(1.0) \mathrm{a}$ & $20.9(2.9) \mathrm{a}$ & $38.8(3.9) b$ & $46.1(5.5) c$ \\
\hline $100 \%$ crown scorch $(n)$ & 0 & 3 & 1 & 8 \\
\hline Mean trunk char ht (cm) & $6.3(2.3) \mathrm{a}$ & $24(4.1) a b$ & $17(6.6) \mathrm{b}$ & $8.3(2.7) \mathrm{a}$ \\
\hline \multicolumn{5}{|l|}{ Fire effects } \\
\hline Fire scars $(\%)$ & 9.1 & 6.3 & 15.6 & 3.9 \\
\hline Mean trunk scar ht (cm) & $30(10.1)$ & $41(23.5)$ & $40.2(9.9)$ & $81.5(60.5)$ \\
\hline Aboveground mortality & 0 & 3 & 1 & 0 \\
\hline
\end{tabular}




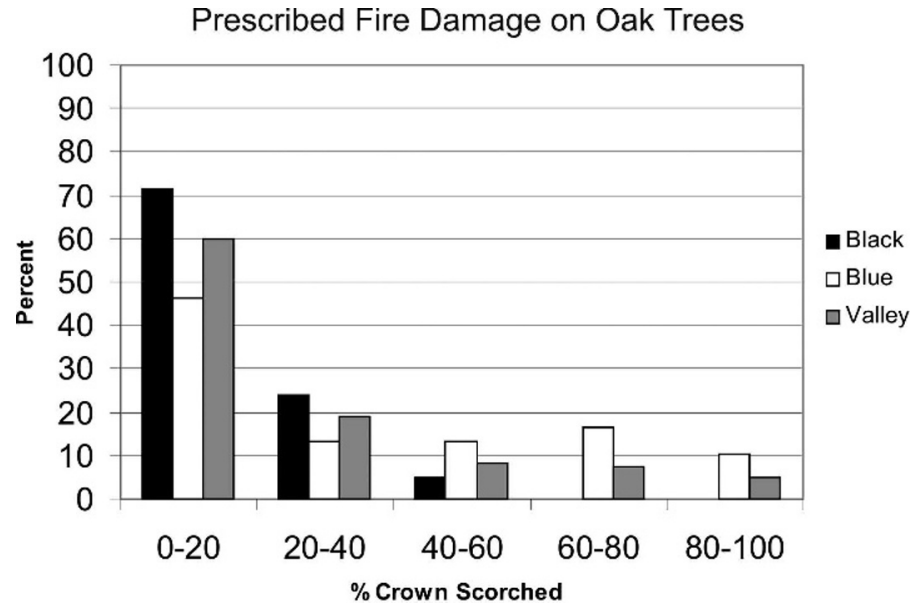

Figure 1. Percent crown scorched by size class for three species of deciduous oaks following a late-spring prescribed fire on the northern Diablo Range, California $(n=208)$.

Estimates of both mean crown scorch $(\mathrm{KW}=52.761$, $\mathrm{df}=3$, $P=0.000)$ and mean trunk char height $(\mathrm{KW}=17.832, \mathrm{df}=3$, $P=0.000$ ) were significantly different among plots (Table 2 ). Mean crown scorch on the SWEST plot was significantly higher than all other plots with $18.2 \%$ of the sampled trees having completely scorched crowns. Conversely, mean trunk char height for SWEST was not significantly different from the lower fire intensity plots.

\section{Trunk Scarring}

Only $7.2 \%$ of the sampled trees had old trunk scars. Many more old scars were found on black oaks $(33.3 \%)$ compared to blue oaks $(4.5 \%)$ and valley oaks $(4.2 \%)$. Heat kill to the cambium inducing new trunk scars occurred on 19 trees $(9.1 \%) ; 42.1 \%$ of these trees had pre-existing scars. Although only $32 \%$ of the total number of new scars was found on black oaks, $29 \%$ of the sampled black oak trees developed

\section{Trunk Scars on Oaks After a Prescribed Fire}

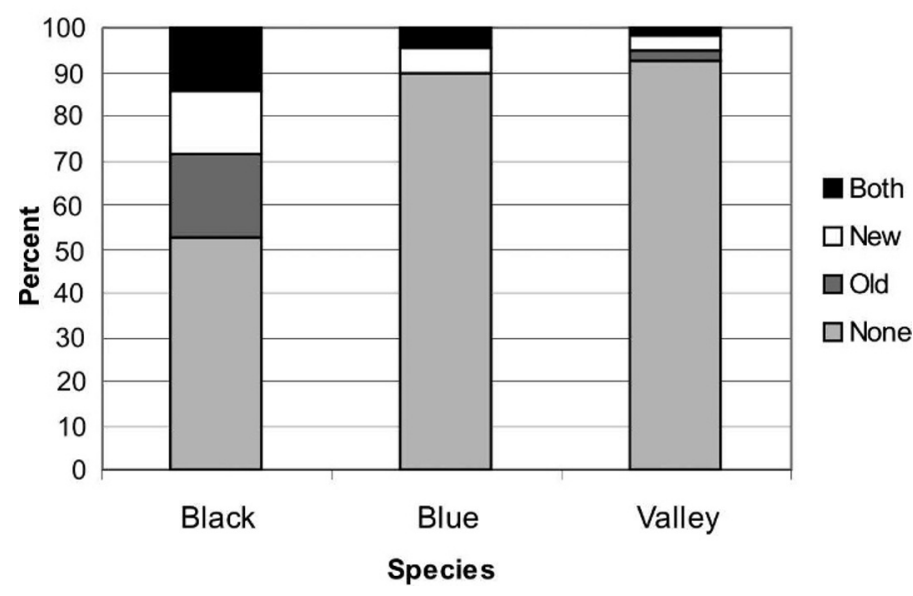

Figure 2. Percentage of oak trees by species with no visible trunk scars (None), old trunk scars only (Old), new fire-induced trunk scars only (New), or presence of both old and new trunk scars (Both). Trees were assessed 4 yr after a late-spring prescribed fire on the northern Diablo Range, California $(n=208)$. new scars (Fig. 2). This was approximately three times the proportion of blue oaks $(11 \%)$ and six times the proportion of valley oaks $(5 \%)$.

There was no significant difference in the formation of new trunk scars between plots $\left(\chi^{2}=5.42, \mathrm{df}=3, \quad P=0.140\right.$; Table 2). CT analysis identified the relative importance of fire damage, tree size, and site characteristics in explaining the development of new trunk scars on trees (Fig. 3A). Trunk char height was the most important factor in explaining the presence of new scars. All trees with maximum char height less than $14.5 \mathrm{~cm}$ did not develop new scars. For trees with maximum char height greater than $14.5 \mathrm{~cm}, \mathrm{DBH}$ was the next most important variable, splitting the group at $34.5 \mathrm{~cm}$. Trees with DBH less than $34.5 \mathrm{~cm}$, mostly blue and valley oaks, did not develop new trunk scars. Finally, most of the larger trees that developed new scars were located on mesic slopes (northwest to east). The explanatory power of the last two variables was due, in part, to the distribution of mature black oaks that developed new scars.

\section{Mortality}

Only four trees died (1.9\%) 4 yr after the burn (Table 2). One mature valley oak with a hollowed out trunk fell within 1 yr of the fire (2000). In 2001, two mature trees died: a black oak and a valley oak. The valley oak had a thin crown before the fire; although it resprouted from the crown and trunk immediately following the fire, there was no green foliage in 2001 and it was presumed dead. In 2003, a relatively small blue oak failed to resprout. Two of the four trees that died had pre-existing, partially hollowed out trunks, which allowed the fire to burn within and the weakened trees eventually fell. None of these trees have since resprouted from the base. The deficiency of dead trees from this burn prohibited any statistical analysis on tree mortality.

\section{Recovery}

One yr after the fire, crown resprouts occurred on $71.5 \%$ of the trees sampled and new sprouts were seen developing on tree crowns as soon as 2 wk after the fire. Only a few trees $(3.8 \%)$ resprouted along the trunk. Most of the blue oak and valley oak trees $(73.2 \%$ and $81.3 \%$, respectively) that were scorched resprouted from the crown. Conversely, none of the black oaks with greater than $20 \%$ scorch resprouted. Resprouting occurred on at least $50 \%$ of the trees with minimal crown scorch $(<20 \%$; Fig. 4$)$.

There was a significant difference in the number of trees resprouting among plots $\left(\chi^{2}=27.6, \mathrm{df}=3, P=0.000\right)$. The NWEST plot had the lowest percentage $(46.9 \%)$ of resprouting trees. CT analysis identified the relative importance of fire damage, tree size, and site characteristics in explaining postburn tree crown resprouting (Fig. 3B). Aspect was the most important variable in explaining the presence of resprouts found on sampled trees. On slopes where most of the trees resprouted, percent crown scorch was an important factor in splitting this group. All trees with greater than $40 \%$ crown scorch resprouted. Most of the larger trees $(>35.7 \mathrm{~cm} \mathrm{DBH})$ with less than $40 \%$ crown scorch developed resprouts after the fire. Finally, all the smaller trees on the high fire intensity plot (SWEST) resprouted. 


\section{Factors Influencing Fire Damage and Recovery of Oak Trees}

A

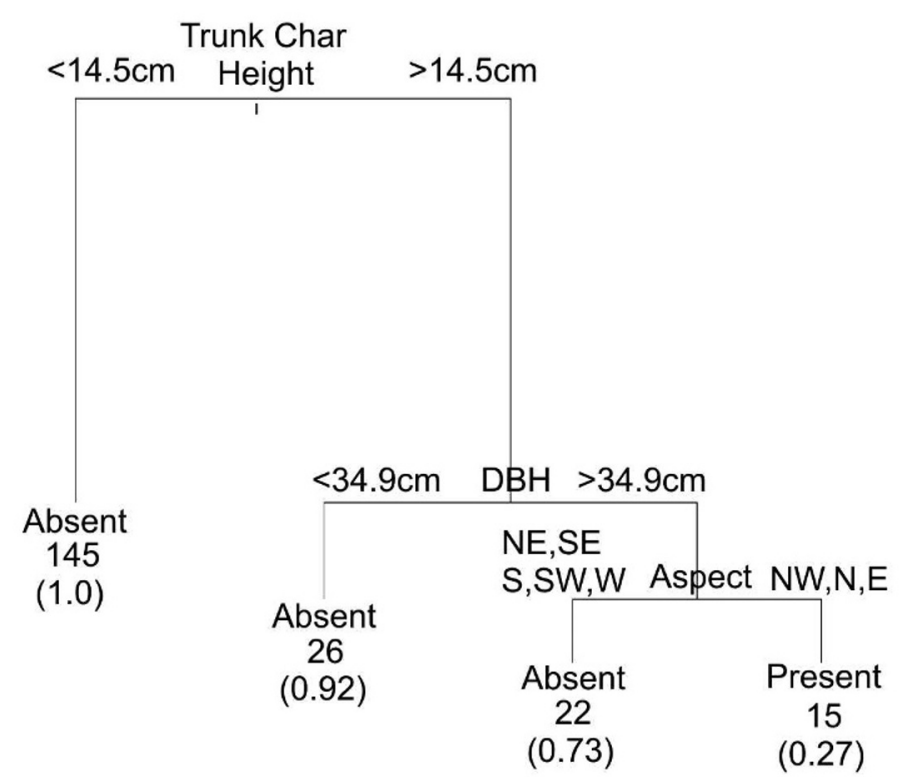

B

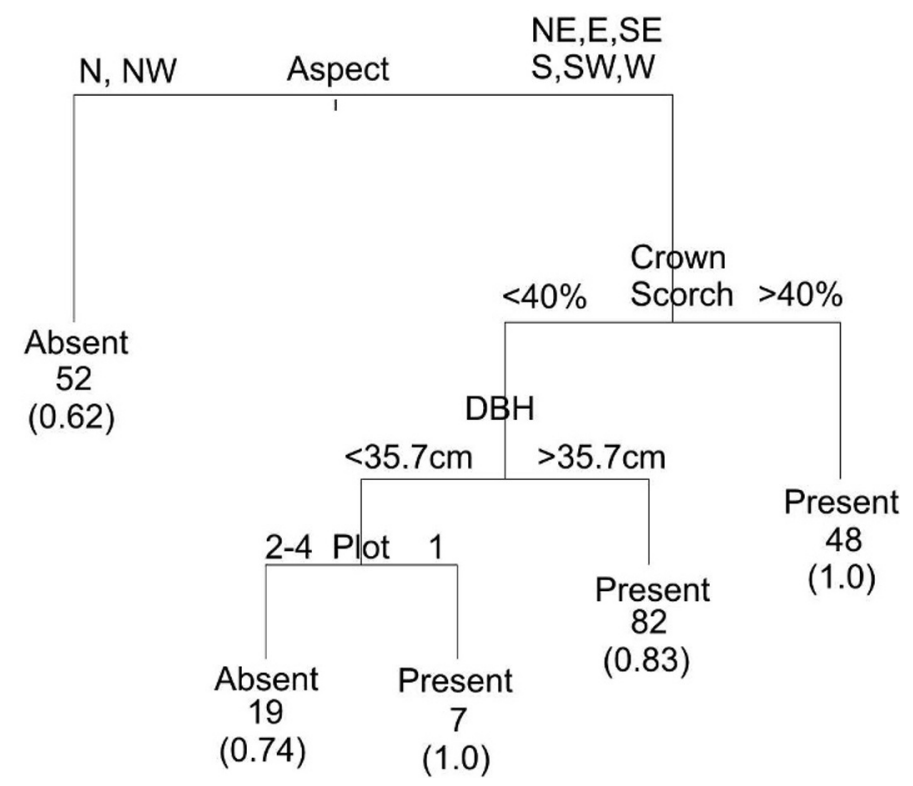

Figure 3. Classification trees on the presence-absence of new trunk scars (A) and resprouting (B) on trees following a late-spring prescribed fire in deciduous oak woodlands in the northern Diablo Range, California. Each terminal node, or leaf, is labeled (classified) according to whether new trunk scars or postburn resprouting is predominately present or absent, the number of observations in the group, and the percentage of observations in that class (in parentheses). The length of the line from each split indicates the relative proportion of deviance explained by that split. $\mathbf{A}$, the misclassification error rate is $5.8 \%$ compared to $4.8 \%$ for the null model. B, the misclassification error rate is $18.8 \%$ compared to $12 \%$ for the null model. For the split involving plot, 1 represents the southwest (SWEST) plot and 2-4 represent all other plots.

\section{Changes to Stand Structure}

For all plots combined, mean crown closure was $44.1 \%$ $(\mathrm{SE}=3.9)$ after the burn in 1999 and increased significantly to $46.7 \%(\mathrm{SE}=3.7)$ in 2001 and $47.4 \% \quad(\mathrm{SE}=3.8)$ in 2003 (rmANOVA $F$ statistic $=6.312, P=0.003$ ). Only the higher fire intensity plots, NWEST and SWEST, had initial increases $(13.8 \%$ and $15.2 \%$, respectively; Fig. 5$)$. There were no

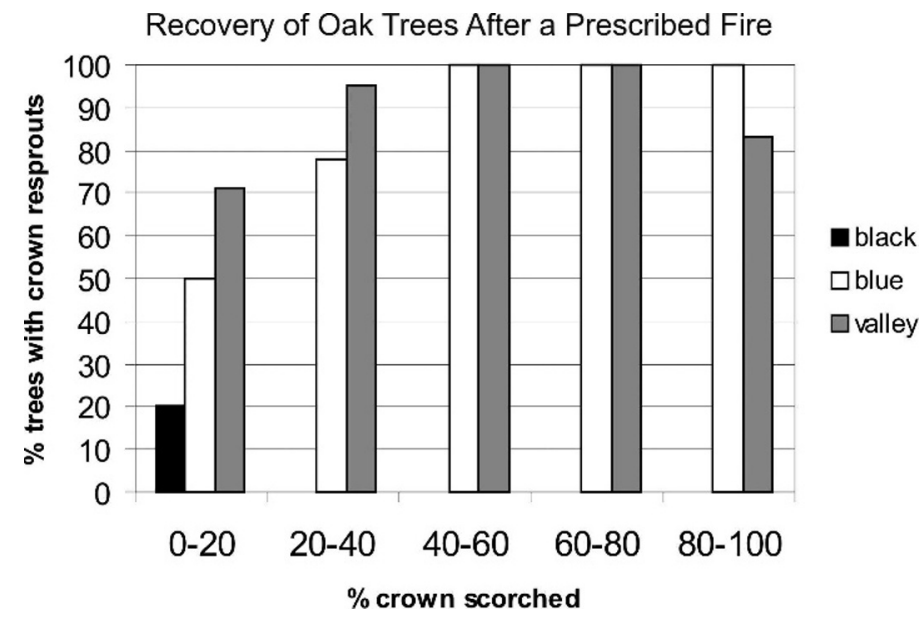

Figure 4. Tree crown resprouting as a function of percent crown scorch in deciduous oak woodlands following a late-spring prescribed fire on the northern Diablo Range, California $(n=208)$. significant difference in mean crown closure between fire intensity plots $(F=0.647, P=0.589)$, but the time-plot interaction was significant $(F=4.118, P=0.001)$.

Total live tree density and basal area decreased by $4.1 \%$ and $0.9 \%$, respectively, $4 \mathrm{yr}$ after the burn. The changes were caused by the death of four trees in the SEAST and NWEST plots. The largest change was the replacement of a valley oak

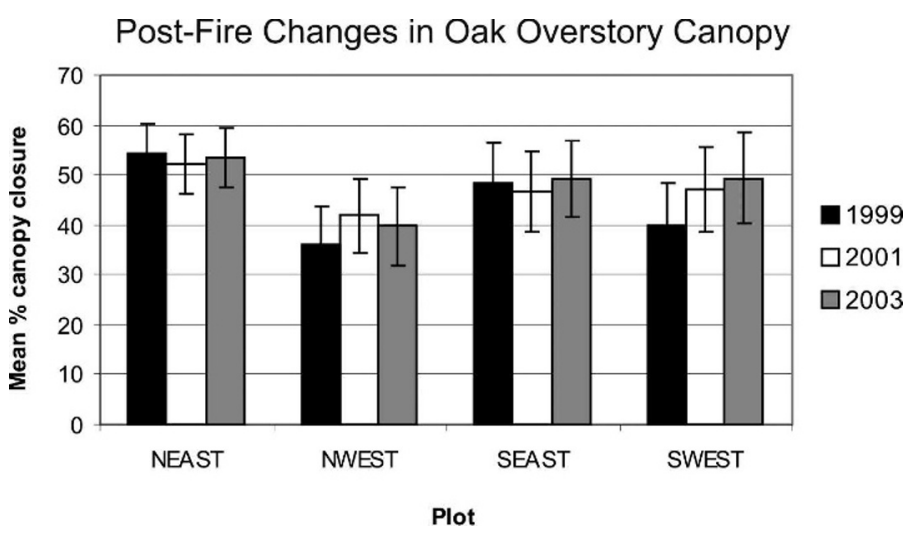

Figure 5. Mean overstory crown closure by plot in deciduous oak woodlands recorded immediately following a late-spring prescribed fire (1999), and 2 and 4 yr postburn (2001 and 2003, respectively) on the northern Diablo Range, California. Error bars represent one standard error of the mean. 
snag by a large coast live oak $\left(1.4-\mathrm{m}^{2}\right.$ basal area) in the postburn survey. Overall, this only slightly changed frequency of species with coast live oak increasing to $0.9 \%$ and valley oak decreasing to $54.8 \%$ (Table 1 ).

\section{DISCUSSION}

Plots that varied in fire intensity (identified from field observations) corresponded with the degree of crown damage but not with trunk char height or the occurrence of trunk scarring. The low mortality $(1.9 \%$ for black, blue, and valley oaks combined) and complete recovery of trees-even with $100 \%$ crown scorch-illustrates the tolerance of oaks to this late-spring prescribed fire. Although sensitivity to fire varies among species, adult tree mortality in oak woodlands is generally low, ranging from $1.5 \%$ (this work) to $12 \%$ (by density; Roy and Vankat 1999) for blue oak following prescribed fires, to $2 \%-48 \%$ for blue, black, and valley oaks (Griffin 1979; Plumb 1979; Haggerty 1994; Horney et al. 2002) following higher-intensity wildfires.

The low mortality rate in this study prohibited an analysis of fire damage-mortality relationships. Under severe wildfire conditions, an estimation of crown scorch has been a useful predictor of tree mortality (Griffin 1980; Haggerty 1994; Horney et al. 2002). Additionally, Horney et al. (2002) found fire damage assessments related to the tree trunk (e.g., char severity ratings, percent charred) were good predictors of mortality for both young and old blue oaks. Under more moderate conditions similar to this study, bark char and trunk scar information might be the most important damage characteristics in estimating long-term mortality and future stand structural characteristics (Standiford and Tinnin 1996).

Several tree and fire behavior characteristics interact to influence the heat transferred to the cambium (Plumb 1979; Plumb and Gomez 1983). The percentage of trees that developed new fire-induced trunk scars was disproportionately higher for black oak compared to blue oak and valley oak. Although black oaks have relatively thick bark, the cambium is sensitive to heat damage (Plumb and Gomez 1983). Not much has been reported in the literature regarding trunk scarring after fire. In this study, only a small number of trees $(9.1 \%)$ developed new scars; however, damage can be extensive as reported in Haggerty (1994), who found 59\% of blue oaks with new trunk scars after a severe widlfire. This effect can cause long-term damage by predisposing trees to rot and failure (Plumb 1979).

Stand structure (species composition, tree density, and basal area) was minimally changed $4 \mathrm{yr}$ after the prescribed fire. Crown closure showed only an initial stimulatory effect and this was primarily in areas of higher fire intensity where trees received more crown scorch. This is noteworthy, considering this was the first fire in this area since at least 1950 (Davis and Borchert 2006; J. Wilcox, personal communication, June 2000). Further use of fire in these woodlands might induce additional changes to stand structure, in part due to cumulative fire damage to tree trunks leading to mortality, especially in areas where black oak occurs. Given the concern for possible adverse effects when reintroducing fire into areas where it has been absent for long periods (Wills 2006), the effect of this fire on stand structure is encouraging.

\section{MANAGEMENT IMPLICATIONS}

Before management plans can be carried out, assessments of stand structure, tree status, and regeneration potential must be documented so that baseline information is available to monitor for changes (Standiford and Tinnin 1996; Horney et al. 2002). Continued use of fire might accelerate changes to oak woodland stand structure, primarily through overstory canopy gap formation from tree mortality, which can be important for regeneration. Resource changes in newly formed gaps allow the seedling bank, often found underneath and along the edge of the overstory canopy, opportunities for growth (Swiecki et al. 1997). Teasing out the impacts of canopy gaps on regeneration is a complex challenge, because oak overstory canopies also influence understory species composition (e.g., Borchert et al. 1989; Jackson et al. 1990), forage quality (e.g., Kay 1987), and nutrient cycling (e.g., Kay 1987; Jackson et al. 1990), all of which need more research in relation to fire.

If regeneration is the primary management goal, then it is suggested that fire be used sparingly (Bartolome et al. 2002). Although oak seedlings and saplings resprout after fire (Swiecki and Bernhardt 2001; Tietje et al. 2001), mortality or topkill retards the transition to the overstory, impeding regeneration (Swiecki et al. 1990, 1997; Tietje et al. 2001; Bartolome et al. 2002; Swiecki and Bernhardt 2002). Longer fire-free intervals allow saplings to grow tall enough to withstand browse pressure and subsequent fires (Swiecki et al. 1990; Allen-Diaz and Bartolome 1992; Swiecki and Bernhardt 2002). Studies have suggested that intervals of at least 10-14 yr might be necessary for this transition (Bartolome et al. 2002; Swiecki and Bernhardt 2002).

Although prescribed fire is a viable tool for reducing fuels and maintaining oak woodlands, including attenuating adverse affects of high intensity wildfires (Franklin et al. 2006), further investigations that include the ecological relationships of oak communities, and long-term fire programs are needed (Standiford and Tinnin 1996). Air quality restrictions, health and safety concerns, and resource limitations likely will continue to pose a challenge for the use of prescribed burning. The CDF calls for investigating fire's natural role in California's ecosystems and, considering that wildfire is responsible for $11 \%-90 \%$ of the conversion of oak woodlands (CDF 2003), the need to more clearly understand fire's role is urgent. Oaks are long-lived species so interpreting the impacts of fire on regeneration and future stand conditions will require an evaluation of several decades of both site history and monitoring (Swiecki and Bernhardt 1997).

\section{ACKNOWLEDGMENTS}

This project was partially funded by a grant (CARO 072800-RW) supported by The Nature Conservancy. The author is grateful to the following for their support, advice, suggestions and offerings: Jeff Wilcox, Robin Wills, Louis Frankel, Jana Nisbet, and the owners of Blue Oak Ranch for allowing me to conduct this study on their property. 


\section{LITERATURE CITED}

Allen-Diaz, B. H., and J. W. Bartolome. 1992. Survival of Quercus douglasii (Fagaceae) seedlings under the influence of fire and grazing. Madroño 39:7-53.

Anderson, H. E. 1982. Aids to determining fuel models for estimating fire behavior. General Technical Report INT-122. Ogden, UT, USA: Department of Agriculture, Forest Service, Intermountain Forest and Range Experiment Station. $28 \mathrm{p}$.

Barbour, M. G. 1988. California upland forests and woodlands. In: M. G. Barbour and W. D. Billings [EDS.]. North American terrestrial vegetation. New York, NY, USA: Cambridge University Press. p. 131-164.

Barnhart, S. J., J. R. McBride, and P. Wagner. 1996. Invasion of northern oak woodlands by Pseudotsuga menziesii (Mirb.) Franco in the Sonoma Mountains of California. Madroño 43:28-45.

Bartolome, J. W., M. P. McClaran, B. H. Allen-Diaz, J. Dunne, L. D. Ford, R. B. Standiford, N. K. McDougald, and L. C. Forero. 2002. Effects of fire and browsing on regeneration of blue oak. In: R. B. Standiford, D. McCreary, and K. L. Purcell (TECH. COORDS.). Proceedings of the Fifth Symposium on Oak Woodlands: Oaks in California's Changing Landscape; 22-25 October 2001; San Diego, CA, USA. Albany, CA, USA: US Department of Agriculture, Forest Service, Pacific Southwest Forest and Range Experiment Station, General Technical Report PSW-184. p. 281-286.

BoLsingeR, C. L. 1988. The hardwoods of California's timberlands, woodlands and savannas. Resource Bulletin-148. Portland, OR, USA: US Department of Agriculture, Forest Service, Pacific Northwest Research Station. 148 p.

Borchert, M. I., F. W. Davis, J. Michaelsen, and L. D. Oyler. 1989. Interactions of factors affecting seedling recruitment of blue oak (Quercus douglasii) in California. Ecology 70:389-404.

Breiman, L., J. H. Friedman, R. A. Olshen, and C. J. Stone. 1984. Classification and regression trees. Belmont, CA, USA: Wadsworth International Group. 358 p.

[CDF] California Department of Forestry and Fire Protection. 1996. California fire plan-a framework for minimizing costs and losses from wildland fires. Sacramento, CA: California Department of Forestry and Fire Protection, Report to California Board of Forestry. $104 \mathrm{p}$.

[CDF] California Department of Forestry and Fire Protection. 2003. The changing California: forest and range 2003 Assessment. Sacramento, CA, USA: California Department of Forestry and Fire Protection: Fire and Resource Assessment Program. 193 p.

Cottam, G., and J. T. Curtis. 1956. The use of distance methods in phytosociological sampling. Ecology 37:451-460.

Davis, F. W., and M. I. Borchert. 2006. Central coast bioregion. In: N. G. Sugihara, J. W. van Wagtendonk, J. Fites-Kaufman, K. E. Shaffer, and A. E. Thode [EDS.]. Fire in California ecosystems. Berkeley, CA, USA: University of California Press. p. 321-349.

DE'Ath, G., and K. E. Fabricius. 2000. Classification and regression trees: a powerful yet simple technique for ecological data analysis. Ecology 81:3178-3192.

Franklin, J., L. A. Spears-Lebrun, D. H. Deutschman, and K. Marsden. 2006. Impact of a high-intensity fire on mixed evergreen and mixed conifer forests in the peninsular ranges of southern California, USA. Forest Ecology and Management 235:18-29.

Griffin, J. R. 1977. Oak woodlands. In: M. G. Barbour and J. Major [eds.]. Terrestrial vegetation of California. New York, NY, USA: Wiley. p. 383-416.

GRIFFIN, J. R. 1980. Sprouting in fire-damaged valley oaks, Chews Ridge, CA. In: Proceedings of the Symposium on the Ecology, Management, and Utilization of California Oaks. Berkeley, CA, USA: US Department of Agriculture, Forest Service, Pacific Southwest Forest and Range Experiment Station, General Technical Report PSW-44. p. 216-219.

Giffin, J. R., And P. C. Muick. 1984. California oaks: past and present. Fremontia 18:4-11.

HAGGeRTY, P. K. 1994. Damage and recovery in southern Sierra Nevada foothill oak woodland after a severe ground fire. Madroño 41:185-198.

Horney, M., R. B. Standiford, D. McCreary, J. Tecklin, and R. Richards. 2002. Effects of wildfire on blue oak in the northern Sacramento Valley. In: R. B. Standiford, D. McCreary, and K. L. Purcell (TECH. COORDS.). Proceedings of the Fifth Symposium on Oak Woodlands: Oaks in California's Changing Landscape; 22-
25 October 2001; San Diego, CA, USA. Albany, CA, USA: US Department of Agriculture, Forest Service, Pacific Southwest Forest and Range Experiment Station, General Technical Report PSW-184. p. 261-267.

Jackson, L. E., R. B. Strauss, M. K. Firestone, and J. W. Bartolome. 1990. Influence of tree canopies on grassland productivity and nitrogen dynamics in deciduous oak savanna. Agriculture, Ecosystems and Environment 32:89-105.

KaY, B. L. 1987. Long-term effect of blue oak removal on forage production, forage quality, soil, and oak regeneration. In: T. R. Plumb and N. H. Pillsbury (TECH. COORDS.). Proceedings of the Symposium on Multiple-Use Management of California's Hardwood Resources; 12-14 November 1986; San Luis Obispo, CA, USA. Berkeley, CA, USA: US Department of Agriculture, Forest Service, Pacific Southwest Forest and Range Experiment Station, General Technical Report PSW-100. p. 351-357.

LeE, D. E., and W. D. Tietse. 2005. Dusky-footed woodrat demography and prescribed fire in a California oak woodland. Journal of Wildlife Management 69:1211-1220.

McClaran, M. P., and J. W. Bartolome. 1989. Fire related recruitment in stagnant Quercus douglasii populations. Canadian Journal of Forest Research 19:580-585

Mensing, S. 1992. The impact of European settlement on blue oak (Quercus douglasii) regeneration and recruitment in the Tehachapi Mountains, California. Madroño 39:36-46.

NeweLL, L. A. 1983. The fire ecology of some major California oaks. In: P. Bowler and S. Brown [EDS.]. The Proceedings of the California Oak Heritage Conservation Conference. Santa Ana, CA, USA: Sea and Sage Audubon Society. p. 82-104.

Parsons, D. J. 1981. The historical role of fire in the foothill communities of Sequoia National Park. Madroño 28:111-120.

Pavlik, B. M., P. C. Muick, S. G. Johnson, and M. Popper. 1991. Oaks of California. Los Olivos, CA, USA: Cachuma Press. 194 p.

PLumB, T. R. 1979. Response of oaks to fire. In: Proceedings of the Symposium on the Ecology, Management, and Utilization of California Oaks. Berkeley, CA, USA: US Department of Agriculture, Forest Service, Pacific Southwest Forest and Range Experiment Station, General Technical Report PSW-44. p. 205-215.

Plumb, T. R., and A. P. Gomez. 1983. Five southern California oaks: identification and postfire management. Berkeley, CA, USA: US Department of Agriculture, Forest Service, Pacific Southwest Forest and Range Experiment Station, General Technical Report PSW-71. 57 p.

PollaRd, J. H. 1971. On distance estimators of density in randomly distributed forests. Biometrics 27:991-1002.

Reid, L. J., and N. G. SugiHara. 1987. Northern oak woodlands-ecosystem in jeopardy or is it already too late? In: T. R. Plumb and N. H. Pillsbury (TECH. CooRDs.). Proceedings of the Symposium on Multiple-Use Management of California's Hardwood Resources; 12-14 November 1986; San Luis Obispo, CA, USA. Berkeley, CA, USA: US Department of Agriculture, Forest Service, Pacific Southwest Forest and Range Experiment Station, General Technical Report PSW-100. p. 59-63.

Rothermel, R. C. 1983. How to predict spread and intensity of forest and range fires. Ogden, UT, USA: US Department of Agriculture, Forest Service, Intermountain Forest and Range Experiment Station, General Technical Report INT-143. $161 \mathrm{p}$.

Roy, D. G., AND J. L. Vankat. 1999. Reversal of human-induced vegetation changes in Sequoia National Park, California. Canadian Journal of Forest Research 29:399-412.

Standiford, R. B., and P. Tinnin. 1996. Guidelines for managing California's hardwood rangelands. Oakland, CA, USA: University of California Division of Agriculture and Natural Resources Leaflet 3368. 173 p.

Swiecki, T. J., and E. A. Bernnardt. 2002. Effects of fire on naturally occurring blue oak (Quercus douglasii) saplings. In: R. B. Standiford, D. McCreary, and K. L. Purcell (TECH. COORDS.). Proceedings of the Fifth Symposium on Oak Woodlands: Oaks in California's Changing Landscape; 22-25 October 2001; San Diego, CA, USA. Albany, CA, USA: US Department of Agriculture, Forest Service, Pacific Southwest Forest and Range Experiment Station, General Technical Report PSW-184. p. 251-259. 
Swiecki, T. J., E. A. Bernhardt, and R. A. Arnold. 1990. Impacts of diseases and arthropods on California's rangeland oaks. Report to Forest and Rangeland Resources Assessment Program, Contract 8CA74545. Sacramento, CA, USA: California Department of Forestry and Fire Protection. $94 \mathrm{p}$.

Swiecki, T. J., E. A. Bernhardt, and C. Drake. 1997. Factors affecting blue oak sapling recruitment. In: Proceedings of a Symposium on Oak Woodlands: Ecology, Management and Urban Interface Issues. Berkeley, CA, USA: US Department of Agriculture, Forest Service, Pacific Southwest Forest and Range Experiment Station, General Technical Report PSW-160. p. 157-168.

Tietse, W. D., J. K. VReeland, and W. H. WeitKamp. 2001. Live oak saplings survive prescribed fire and sprout. California Agriculture 55:18-22.

Tietse, W. D., K. L. Waddell, J. K. Vreeland, and C. L. Bolsinger. 2002. Coarse woody debris in oak woodlands of California. Western Journal of Applied Forestry $17: 139-146$
Vreeland, J. K., and W. D. Tietue. 2002. Numerical response of small vertebrates to prescribed fire in a California oak woodland. In: R. B. Standiford, D. McCreary, and K. L. Purcell (TECH. COORDS.). Proceedings of the Fifth Symposium on Oak Woodlands: Oaks in California's Changing Landscape; 22-25 October 2001; San Diego, CA, USA. Albany, CA, USA: US Department of Agriculture, Forest Service, Pacific Southwest Forest and Range Experiment Station, General Technical Report PSW-184. p. $269-279$.

WiLLs, R. 2006. Central valley bioregion. In: N. G. Sugihara, J. W. van Wagtendonk, J. Fites-Kaufman, K. E. Shaffer, and A. E. Thode [EDS.]. Fire in California Ecosystems. Berkeley, CA, USA: University of California Press. $p$. 295-320.

ZAR, J. H. 1999. Biostatistical Analysis. 4th ed. Upper Saddle River, NJ, USA: Prentice Hall. $663 p$. 